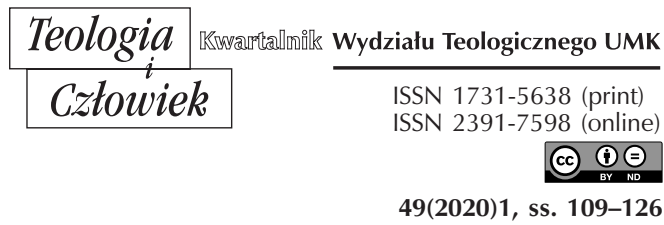

KS. STANISŁAW SUWIŃSKI

UNIWERSYTET MIKOŁAJA KOPERNIKA W TORUNIU

STANSU25@UMK.PL

ORCID 0000-0001-9792-0855

\title{
OSOBY STARSZE I RODZINA W SYSTEMIE SPOŁECZNYM - Z PERSPEKTYWY DOMU POMOCY SPOŁECZNEJ W BROWINIE
}

DOI: http://dx.doi.org/10.12775/TiCz.2020.006

Streszczenie. Prezentowany artykuł jest próbą spojrzenia na współczesny problem starzenia się społeczeństwa, które domaga się nowych wyzwań wobec wzrastającej liczby seniorów. Nie można zgodzić się na wykluczenie tej grupy społecznej, lecz należy odnaleźć sposób na ich konkretne zaangażowanie w życiu wspólnotowym. Istotnym zadaniem jest także zorganizowanie dla nich pomocy zarówno ze strony rodziny, jak i instytucji, aby w ten sposób respektować godność osoby ludzkiej, przysługującą każdemu człowiekowi. Autor powyższy problem ukazuje na przykładzie Domu Pomocy Społecznej w Browinie, położonym w gminie Chełmża.

Słowa klucze: osoby starsze; rodzina; opieka społeczna; wsparcie duchowe.

Abstract. The elderly and the family in the social system from the perspective of the Nursing Home in Browina. The article below makes an attempt to face the contemporary problem of ageing which requires new challenges in the face of the growing number of seniors. It is not acceptable to agree to the exclusion of this social group, but it is essential to find a way to engage them in social life. A key task is to provide help for them both from families and institutions in order to respect the dignity of a human being that every person deserves. The Author presents the above problem from the perspective of the Nursery Home in Browina located near Chełmża, Poland.

Keywords: the elderly; family; social care; spiritual support. 


\section{WSTĘP}

Na początku XXI wieku proces starzenia się społeczeństwa traktować można nie tylko jako zagrożenie, ale również jako wyzwanie. $Z$ jednej strony osoby starsze obawiają się osamotnienia, zniedołężnienia czy ubóstwa, z drugiej marzą o zachowaniu kondycji, towarzystwie i możliwości korzystania z nagromadzonych przez całe życie oszczędności. Starzenie się społeczeństwa to jeden z głównych czynników, które wpływają na zwiększenie się zapotrzebowania w zakresie opieki społecznej ${ }^{1}$. Dotyczy to zarówno opieki sprawowanej przez rodzinę czy znajomych, jak i opieki świadczonej przez profesjonalne służby. W myśl zasady subsydiarności, pomoc instytucjonalna powinna być świadczona wówczas, kiedy wsparcie rodziny oraz najbliższego otoczenia osoby w podeszłym wieku nie jest wystarczające ${ }^{2}$.

W Polsce pomoc instytucjonalną świadczy się w ramach dwóch systemów - pomocy społecznej oraz ochrony zdrowia, przy czym stan zdrowia powinien być wyznacznikiem przyznania określonego rodzaju pomocy. W praktyce jednak instytucje, które działają w ramach ochrony zdrowia, pełnią zazwyczaj funkcję substytutów w stosunku do instytucji pomocy społecznej.

Starszy człowiek zazwyczaj potrzebuje pomocy oraz wsparcia ze strony otoczenia. Czynnikami, które utrudniają jego codzienne życie, są przewlekłe choroby, zniedołężnienie, a często także samotność. Osoby starsze nierzadko stają wobec problemów, które przekraczają możliwość

1 „Według klasyfikacji Światowej Organizacji Zdrowia (WHO) osoby starsze dzielą się na trzy grupy: osoby w podeszłym wieku (między 60. a 75. rokiem życia), w wieku starczym (między 75. a 90. rokiem życia) oraz osoby w wieku sędziwym (powyżej 90. roku życia). Z racji biologicznych zwykło się wyodrębniać następujące rodzaje starości: wczesną starość (45-60 lat), starość właściwą (60-75 lat), długowieczność (75-90 lat) oraz makrobiotyzm, czyli wyjątkową długowieczność (ponad 90 lat)": A. Zwoliński, Starość, w: Encyklopedia nauczania społecznego Jana Pawła II, Radom 2003, s. 484. „Łatwiej powiedzieć, kiedy się kończy [wiek starczy]. Ameryka jest optymistyczna uważa się tam, że «siedemdziesiątka dzisiaj jest jak pięćdziesiątka dawniej», i coś w tym jest. Wiadomo - żyjemy dłużej, statystycznie. Tyle, że nikt z nas nie żyje statystycznie, żyjemy naprawdę” - A. Zagajewski, Przyjemności marzyciela, „Tygodnik Powszechny”, 21 czerwca 2015, s. 61.

2 A. Mielczarek, Człowiek stary $w$ domu pomocy społecznej. Z perspektywy polityki społecznej i pracy socjalnej, Toruń 2010, s. 9. 
ich samodzielnego rozwiązania, dlatego szukają wsparcia w instytucjach pomocowych ${ }^{3}$.

\section{CZYM JEST STAROŚĆ?}

Święty Jan Paweł II w liście „Do moich Braci i Sióstr - ludzi w podeszłym wieku” (Watykan, 1 X 1999), postawił pytanie: „Czym jest starość?" Odpowiadając na to pytanie, odwołał się do własnego doświadczenia tego etapu życia w perspektywie całego procesu rozwoju i dojrzewania osoby oraz analogii i związku człowieka $\mathrm{z}$ otaczającym go światem. Określanie jej mianem „jesieni życia” wskazuje na kolejność etapów z właściwą im specyfiką i pięknem. Zwraca jednak uwagę, że „człowiek różni się od całej otaczającej go rzeczywistości, ponieważ jest osobą. Ukształtowany na obraz i podobieństwo Boże, jest świadomym i odpowiedzialnym podmiotem"4.

Święty Jan Paweł II na początku swojego pontyfikatu zwracał uwagę na poszanowanie godności ludzkiej, w tym godności osoby starszej. Współczesność zmagająca się z ogromnym problemem demograficznym - starzeniem się społeczeństw i narodów, nie może zapominać o apelu tego wielkiego człowieka. W okresie, gdy słowa te jeszcze nie ucichły, a zarazem na nowo do nas przemawiają $\mathrm{w}$ związku $\mathrm{z}$ jego niedawną kanonizacją, potrzebna jest refleksja nad podejściem, szczególnie świata nauki i polityki, do kwestii starzenia się i starości. W jednym z przemówień podkreślał, że: „Polityka demograficzna nie może traktować ludzi wyłącznie w kategoriach ilościowych, ekonomicznych ani kierując się jakimikolwiek uprzedzeniami. Musi ona szanować i służyć godności oraz podstawowym prawom osoby ludzkiej"s.

${ }^{3}$ Jan Paweł II, O szacunku dla ludzi w podeszłym wieku. Przemówienie do uczestników konferencji zorganizowanej przez Papieską Radę ds. Duszpasterstwa Służby Zdrowia (Watykan, 31 października 1998), 4.

4 Tenże, List „Do moich Braci i Sióstr - ludzi w podeszłym wieku”, n. 5 (Watykan, 1 października 1999).

5 Tenże, Każda polityka demograficzna musi szanować osobę ludzką, Przemówienie do Sekretarza Generalnego Międzynarodowej Konferencji na temat zaludnienia (Watykan, 7 czerwca 1984). 
Domy pomocy społecznej są placówkami przeznaczonymi dla osób, które nie kwalifikują się do leczenia szpitalnego, lecz z uwagi na podeszły wiek, schorzenia, warunki rodzinne, mieszkaniowe i materialne oraz sytuację życiową wymagają stałej opieki. U ich podstaw organizacyjnych leżą następujące założenia: potrzeba zróżnicowania oraz możliwie maksymalne dostosowanie warunków i charakteru domu do sprawności i stanu zdrowia mieszkańców, systematycznie zmieniające się proporcje liczby miejsc w poszczególnych typach placówek w zależności od potrzeb społecznych oraz nadanie domom charakteru rodzinnego i prywatnego, aby podopieczni czuli się w nich jak najlepiej ${ }^{6}$.

W domach pomocy społecznej zaspokajane są potrzeby bytu związane ze snem, pożywieniem, odzieżą, odpowiednim wyposażeniem pokoju, opieką medyczną, oraz potrzeby społeczne - związane z nawiązywaniem kontaktów społecznych, koniecznością doświadczania bliskości, akceptacji, bycia dla kogoś kimś ważnym i rozumianym, potrzeby kulturalne, religijne czy aktywności.

Niezaspokajanie lub błędy w realizowaniu potrzeb biologicznych prowadzą do powstania zmian chorobowych w organizmie. $Z$ kolei nieprawidłowe zaspokajanie potrzeb psychospołecznych stwarza poczucie pustki, samotności, niesie ze sobą cierpienie, wyzwala mechanizmy obronne, prowadzi do konfliktów jednostki z otoczeniem i może być powodem powstawania nerwic. Świadomość tych konsekwencji powoduje, że przepisy prawa nakładają na placówki obowiązki w zakresie realizacji potrzeb zamieszkujących $\mathrm{w}$ nich osób, ponieważ jest to warunkiem ich prawidłowego rozwoju i dobrego samopoczucia ${ }^{7}$.

\section{OSOBY STARSZE ZAWSZE MIEĆ BĘDZIECIE!}

Zwiększająca się populacja osób w starszym wieku będzie w najbliższych latach podstawowym czynnikiem generującym wzrost zapotrzebowania na różnego rodzaju formy pomocy, w tym pomoc instytucjo-

${ }^{6}$ M. Duda, Wartość ludzkiej starości, w: Życie i śmierć. Wyzwania działalności charytatywnej, red. J. Stala, Tarnów 2012, s. 134.

7 Jan Paweł II, Środki przekazu społecznego a problem ludzi starszych. Orędzie na XVI Światowy Dzień Środków Masowego Przekazu, (Watykan, 10 maja 1982), 1. 
nalną . W orędziu skierowanym do uczestników światowego sympozjum na temat starzenia się ludzkości czytamy: „Życie jest darem, jakiego Bóg udziela ludziom, których z miłości stworzył na swój obraz i podobieństwo. Takie pojmowanie wzniosłej godności ludzkiej osoby prowadzi do uznania waloru każdego etapu życia. Jest to kwestia logiki i sprawiedliwości”"

Powyższa parafraza słów Jezusa: „Bo ubogich zawsze macie u siebie, ale Mnie nie zawsze macie” (J 12, 3-8) stawia nie tylko wyzwanie społeczne, ale także wobec rodziny. Choroba i związane z nią cierpienie przynależą w sposób naturalny do kondycji ludzkiego losu. Normalną reakcją człowieka na doświadczenie choroby jest lęk o siebie, lęk przed przyszłością, lęk wobec ogromu cierpienia. Stąd też sytuacja choroby stanowi wyzwanie moralne i duchowe dla samego chorego, a także dla jego otoczenia: rodziny, przyjaciół, instytucji służby zdrowia oraz Kościoła.

Współcześnie istnieje społeczny problem pewnego wykluczenia osób starszych. Szybki rozwój ekonomiczny i społeczny w dzisiejszych czasach spowodował poważne zmiany w życiu rodzinnym. Ludzie starsi, zdaniem Benedykta XVI, znaleźli się w czymś na kształt „strefy parkingowej”. Niektórzy z nich zaczęli postrzegać siebie jako ciężar dla rodziny i podjęli decyzję o samotnym życiu we własnym mieszkaniu lub w domu spokojnej starości ${ }^{10}$. Ponadto dostrzega się coraz bardziej narastanie „kultury śmierci”, która jest zagrożeniem przede wszystkim dla trzeciego wieku. W krajach, gdzie zalegalizowano eutanazję ${ }^{11}$, np. w Holandii i Belgii, proponuje się nawet przyśpieszenie końca życia, aby w taki sposób rozwiązać trudne i nieraz skomplikowane sytuacje. We współczesnej cywilizacji istnieje nadal, jak zauważa papież Franciszek, niebezpieczeństwo

816 sierpnia 2012 r. w Ministerstwie Pracy i Polityki Społecznej utworzono nowy departament - Departament Polityki Senioralnej. W serwisie internetowym Ministerstwa czytamy: „Departament Polityki Senioralnej odpowiada za tworzenie i rozwój kierunków działań skierowanych do seniorów, warunków dla poprawy systemu wsparcia seniorów, realizację zadań w obszarze aktywnego starzenia się i innych form współpracy wewnątrzi międzypokoleniowej z udziałem seniorów oraz monitorowanie wdrażanych rozwiązań”.

9 Papieska Rada ds. Świeckich, Godność i posłannictwo ludzi starszych, 1.

${ }^{10}$ Benedykt XVI, Dziadkowie sa cennym skarbem każdej rodziny. Przemówienie do uczestników XVIII Zgromadzenia Plenarnego Papieskiej Rady ds. Rodziny (Watykan, 5 kwietnia 2008), s. 1.

${ }^{11}$ J. Dziedzic, Spór o eutanazję, Kraków 2005, s. 41-44. 
wykluczenia najsłabszych, tzw. kultura odrzucenia. „Nie ma miejsca ani dla starca, ani dla niechcianego dziecka. Nie ma czasu, aby zatrzymać się z ubogim na skraju drogi. Czasami wydaje się, że dla niektórych relacje międzyludzkie są regulowane przez dwa nowoczesne «dogmaty»: skuteczność i pragmatyzm”. Do kultury odrzucenia należy również zaliczyć chęć nadmiernego zysku i konsumpcjonizm ${ }^{12}$.

Ważny jest pierwszy moment. Reakcja na chorobę warunkowana jest wieloma czynnikami. Jednym $\mathrm{z}$ nich jest stosunek najbliższego otoczenia, zarówno do choroby, jak i do chorego człowieka. Już sama świadomość akceptacji i wsparcia w społeczeństwie, w grupie zawodowej czy w rodzinie umacnia człowieka $\mathrm{w}$ walce $\mathrm{z}$ chorobą. Niestety, w miarę rozwoju procesu chorobowego ulegają osłabieniu więzi społeczne i zawodowe, zaś dla chorego najważniejsza staje się rodzina. Potrzebuje on wtedy poczucia, że nie stał się ciężarem zbyt trudnym do udźwignięcia dla swoich bliskich i że jego życie w chorobie ma pełny sens ${ }^{13}$.

Czy starość musi, czy nie musi być związana z chorobą? Mówiąc o chorym w rodzinie, niepodobna pominąć ludzi posuniętych w latach. Najczęściej to nasi dziadkowie lub pradziadkowie. Starość nie jest chorobą. Jest jednak tym okresem w życiu człowieka, w którym coraz bardziej zauważa się i odczuwa postępujący ubytek sił, sprawności, większą podatność na choroby. Papież Jan Paweł II starość nazwał czasem, w którym „dopełnia się miara ludzkiego życia”. Zdaniem Papieża, „najbardziej naturalnym środowiskiem przeżywania starości pozostaje to, w którym człowiek w podeszłym wieku czuje się «u siebie» - wśród krewnych, znajomych i przyjaciół, oraz gdzie może być jeszcze w jakiś sposób użytecznym... Dlatego rozwiązaniem idealnym pozostaje obecność człowieka starego w rodzinie"14.

\section{RODZINA UPRZEDNIA WOBEC INSTYTUCJI WSPARCIA}

Najpierw rodzina, a potem systemem społeczny. Jak już zaznaczono wcześniej, w życiu człowieka, a szczególnie starszego, rodzina odgrywa

${ }^{12}$ Franciszek, Papież do duchownych: Nie kierujcie się jedynie skutecznością (Rio de Janeiro, 27 lipca 2013).

${ }^{13}$ K. Wiśniewska-Roszkowska, Starość jako zadanie, Warszawa 1989, s. 33.

${ }^{14}$ Jan Paweł II, List „Do moich Braci i Sióstr - ludzi w podeszłym wieku, n. 24. 
ważną rolę i powinna być podstawowym miejscem bytowania. „Rodzina ma ogromny wpływ na kształtowanie się cech jednostki, cech istotnych dla jej funkcjonowania w życiu. Po drugie rodzina jest najważniejszym terenem, na którym działa jednostka, miejscem gdzie realizuje swoje potrzeby i pragnienia, indywidualne i społeczne cele". Jakość funkcjonowania rodziny ma zatem kluczowe znaczenie dla satysfakcji życiowej jednostki. Cele realizowane przez rodzinę można sprowadzić do zaspokajania indywidualnych potrzeb poszczególnych jednostek oraz wykonywania specyficznych zadań, takich jak wychowywanie dzieci oraz przekazywanie wartości kulturowych. Rodzina jest odpowiedzialna za kształtowanie przyszłych pokoleń i trwanie społeczeństw, zarówno w wymiarze biologicznym, jak i kulturowym. To, w jaki sposób funkcjonuje rodzina, jest ważne w kontekście indywidualnym oraz społecznym. Gdy rodzina zapewnia poczucie bezpieczeństwa oraz zaspokaja potrzeby jednostki, powoduje zadowolenie zarówno tych, którzy ją tworzą, jak i tych, którzy z tego korzystają. Z kolei gdy rodzina nie radzi sobie właściwie, może generować jednostki, które nie są w pełni przystosowane do współżycia społecznego ${ }^{15}$.

Najbardziej naturalnym środowiskiem przeżywania starości jest rodzina. To tu wśród krewnych, znajomych i przyjaciół człowiek w podeszłym wieku czuje się u siebie. Wrażliwość rodzin jest istotna zwłaszcza w ostatnim etapie życia osób starszych. Towarzyszenie w tym czasie bliskim najlepiej weryfikuje istniejące więzi z najbliższymi. O właściwe relacje z najbliższymi upomina się Pismo Święte, kiedy wzywa: „Synu, wspomagaj swego ojca w starości, nie zasmucaj go w jego życiu. A jeśliby nawet rozum stracił, miej wyrozumiałość, nie pogardzaj nim, choć jesteś w pełni sił. Miłosierdzie względem ojca nie pójdzie w zapomnienie [...]. W dzień utrapienia wspomni się o tobie" (Syr 3, 12-15).

Dokonujące się przemiany demograficzne rodziny powodują konieczność rozbudowania systemu instytucjonalnej pomocy społecznej dla osób starszych. Konieczne staje się rozbudowanie pomocy instytucjonalnej skierowanej do osób samotnych nie mających żadnych opiekunów. Pojawiająca się coraz częściej bezdzietność sprawia, że osoby starsze nie mają potencjalnych opiekunów. Dodatkowo nadumieralność mężczyzn sprawia,

15 A.A. Zych, Człowiek wobec starości, Warszawa 1995, s. 37-40. 
że kobiety przebywają dłużej we wdowieństwie i nie mają oparcia we współmałżonku. Należy tworzyć takie systemy opieki, które na pierwszym miejscu stawiają godność człowieka i pomagają mu zachować poczucie własnej wartości, „aby nie doszło do sytuacji, w której poczuje się on bezużytecznym ciężarem i będzie pragnął lub wręcz domagał się śmierci” (EV 94). Dokonujący obecnie szybki rozwój medycyny paliatywnej wychodzi naprzeciw osobom chorym i starym. Współczesna medycyna może dziś uśmierzyć prawie każdy ból. Istotnymi elementami poprawy jakości życia seniora są: humanizacja instytucji opieki socjalnej i ochrony zdrowia, współpraca wolontariuszy, zaangażowanie rodzin.

Instytucjonalne wsparcie społeczne odpowiada na aktualnie pojawiające się potrzeby związane $\mathrm{z}$ wystąpieniem stresujących wydarzeń życiowych takich, jak choroba, utrata pracy, kryzys osobisty, trudności w szkole czy kłopoty rodzinne. System wsparcia społecznego jest niezwykle ważny dla każdego człowieka, a jeszcze większą rolę odgrywa w przypadku ludzi przewlekle chorujących. Naturalna sieć wsparcia w sytuacji wystąpienia poważnej choroby zostaje bardzo ograniczona, a chory często zostaje pozostawiony zupełnie sam. Dlatego tak istotne jest, by system wsparcia zorganizowany wokół pacjenta zadziałał i pomógł mu jak najszybciej wrócić do swoich naturalnych ról społecznych ${ }^{16}$.

\section{DPS W SYSTEMIE POMOCY SPOŁECZNEJ}

Domy pomocy społecznej stanowią ważny element budowanego systemu pomocy społecznej. Posiadają jedne z najstarszych korzeni jako forma pomocy społecznej w zakresie organizowania opieki adresowanej do osób, które bez pomocy osób trzecich nie były wstanie samodzielnie funkcjonować w miejscu zamieszkania. W przeszłości placówki te przeszły liczne przeobrażenia, nie tylko w samej wewnętrznej strukturze organizacyjnej, ale przede wszystkim w postrzeganiu ich przez otoczenie zewnętrzne. Jest to forma pomocy, która pomimo wielu fundamentalnych

16 P. Bronowski, M. Sawicka, S. Kluczyńska, Sieci społeczne osób chorujących psychicznie objętych środowiskowym programem wsparcia i rehabilitacji, „Postępy Psychiatrii i Neurologii” 4 (2008), s. 298. 
zmian zachodzących wewnątrz organizacji, postrzegana jest przez otoczenie zewnętrzne w sposób krzywdzący, jako miejsce o bardzo siermiężnych warunkach zamieszkania, jako ostateczność, „wybór mniejszego zła” w sytuacji braku wystarczającego oparcia ze strony bliskich w środowisku zamieszkania, a przecież są to jednostki o dużym stopniu profesjonalizacji usług, z ich szeroko rozbudowanym wachlarzem, wychodzącym naprzeciw oczekiwaniom osób (i ich rodzin) z nich korzystających.

Dom Pomocy Społecznej w Browinie to złożona instytucja, w której splata się cała różnorodność jego funkcjonowania; niektórzy porównują ten dom pomocy społecznej do złożonego przedsiębiorstwa, w którym zarządza się zasobami, skomplikowanymi mechanizmami, gdzie potrzeby mieszkańców nakładają się na „interesy” personelu, ale w tle jest sprawna infrastruktura, zabezpieczenie finansowania gwarantującego swobodne funkcjonowanie całości. Wymaga to od kadry zarządzającej dużej sprawności organizacyjnej i umiejętności, a także woli racjonalnego zarządzania, posiadania umiejętności godzenia różnych interesów i oczekiwań, czasem skrajnie różnych potrzeb mieszkańców, co wymaga równolegle wysokiej wrażliwości na potrzeby drugiego człowieka, empatii i codziennej troski o mieszkańców, ale i o personel, który w bezpośrednim kontakcie z mieszkańcami domu staje się głównym ogniwem oparcia zapewnianego przez DPS ${ }^{17}$.

Dla kogo są Domy Pomocy Społecznej? Prawo do umieszczenia w domu pomocy społecznej przysługuje osobie wymagającej całodobowej opieki z powodu wieku, choroby lub niepełnosprawności, niemogącej samodzielnie funkcjonować w codziennym życiu, której nie można zapewnić niezbędnej pomocy w formie usług opiekuńczych.

Jak funkcjonuje system prawny w DPS-ie. Nowoczesny system pomocy społecznej w Polsce powstał po roku 1989, a zasady funkcjonowania zostały określone w Ustawie o pomocy społecznej z dnia 29 listopada 1990 r. Ustawa ta zastąpiła najdłużej funkcjonującą ustawę z roku 1923. Na podstawie Ustawy o samorządzie terytorialnym z dnia 8 marca 1990 r. sprawy pomocy społecznej, w tym ośrodków i zakładów opiekuńczych, weszły w zakres zadań własnych gminy (realizowanych z własnych środków finansowych gminy). Obowiązek realizacji znacznej części pomocy społecznej spoczywa na gminie oraz jej organach, szcze-

17 Zob. Z. Grabusińska, Domy pomocy społecznej w Polsce, Warszawa 2013. 
gólnie na ośrodkach pomocy społecznej. Prawo jest ciągle aktualizowane i dostosowywane do obecnych rozwiązań. W latach 2003-2004 pomoc społeczna była przedmiotem dalszych reform, których głównym celem było ograniczenie kosztów jej funkcjonowania. 12 marca 2004 roku została uchwalona nowa ustawa o pomocy społecznej. Przyjęte po roku 1989 ustawy o pomocy społecznej spowodowały jakościową zmianę instytucji pomocy społecznej w Polsce.

Decentralizacja pomocy i przeniesienie części kompetencji na podmioty lokalne oraz tworzenie warunków do rozwoju działalności organizacji pozarządowych jest nawiązaniem do polskiej tradycji rozwoju systemu ochrony socjalnej, a także jest zgodne z rozwiązaniami przyjętymi w krajach UE ${ }^{18}$.

Potrzeba kolejnych nowelizacji ustawy wskazuje na konieczność ciągłego dostosowywania się systemu do zmieniającej się rzeczywistości. Obecnie postępujący proces starzenia się społeczeństwa stawia nowe wyzwania przed pomocą społeczną.

Globalny problem. Występujące w całym świecie procesy starzenia się społeczeństw skutkują większą liczbą osób starszych potrzebujących opieki przy równocześnie zmniejszających się możliwościach sprawowania opieki przez rodziny. Czynnikiem wpływającym na spadek potencjału opiekuńczego rodziny wobec osób starszych są zmiany demograficzne rodziny. Przemiany te odnoszą się do wielkości i struktury rodziny. Żyjemy w sytuacji upadku rodzin wielopokoleniowych.

\section{RODZAJE WSPARCIA INSTYTUCYJNEGO}

Najbardziej znanego podziału wsparcia dokonują H. Sęk i R. Cieślak ${ }^{19}$, którzy wyróżniają jego pięć podstawowych rodzajów: emocjonalne, informacyjne, instrumentalne, rzeczowe i duchowe ${ }^{20}$.

${ }_{18}$ B. Szatur-Jaworska, Ludzie starzy i starość w polityce społecznej, Warszawa 2000, s. 34.

${ }^{19}$ H. Sęk, R. Cieślak, Wsparcie społeczne - sposoby definiowania, rodzaje i źródła wsparcia. Wybrane koncepcje teoretyczne, w: Wsparcie społeczne, stres $i$ zdrowie, red. tychże, Warszawa 2005, s. 19-20.

${ }_{20}$ Zob. A. Leszczyńska-Rejchert, Człowiek starszy i jego wspomaganie - w strone pedagogiki starości, Olsztyn 2010, s. 48-51. 
Wsparcie emocjonalne to najczęściej występujący rodzaj wsparcia. Polega na przekazywaniu drugiemu człowiekowi emocji będących wyrazem troski i pozytywnego nastawienia do osoby wspieranej, mający charakter uspokajający, wspierający i podtrzymujący na duchu. Taki rodzaj wsparcia wpływa na wytworzenie się poczucia przynależności, posiadania opieki, podwyższa samoocenę i poprawia samopoczucie osoby wspieranej. Osoby aktualnie przeżywające problemy dzięki wsparciu emocjonalnemu mają szansę wyrażenia swoich emocji, smutków i negatywnych uczuć, a jednocześnie wzmocnienia nadziei, że trudności, z którymi się zmagają, da się rozwiązać ${ }^{1}$.

Wsparcie informacyjne polega na wymienianiu informacji mających na celu lepsze zrozumienie sytuacji problemowej, w której znalazła się osoba wymagająca wsparcia, a także na udzielaniu informacji zwrotnych, czy dotychczas podejmowane wysiłki są skuteczne. Wsparcie informacyjne przybiera formę dzielenia się swoją wiedzą i życiowymi doświadczeniami z osobami, które obecnie zmagają się z podobnymi problemami. Zwykle ten rodzaj wsparcia ma miejsce w grupach samopomocowych, gdzie służy lepszemu zrozumieniu sensu i przyczyn występowania różnych trudności, a także wykształceniu poczucia sprawstwa w ich rozwiązywaniu.

Wsparcie instrumentalne jest rodzajem modelowania zachowań osoby wymagającej wsparcia i występuje wówczas, gdy osoba wspierająca udziela instrukcji, w jaki sposób można postąpić w sytuacji stanowiącej aktualny problem. Mogą to być instrukcje dotyczące konkretnych działań czy też sposobu na zdobycie informacji lub potrzebnych dóbr materialnych.

Wsparcie rzeczowe (materialne) polega na bezpośrednim, fizycznym działaniu i przekazywaniu środków materialnych, rzeczowych lub finansowych na rzecz osób potrzebujących wsparcia. Może odbywać się poprzez zapewnienie noclegu, żywności, leków czy pieniędzy. Ten rodzaj wsparcia jest ściśle związany z działalnością charytatywną i zwykle jest lepiej rozwinięty w społecznościach altruistycznych, gdzie wartością jest pomaganie innym ludziom. Wsparcie rzeczowe pełni niezwykle istotną rolę w sytuacjach nieprzewidzianych katastrof bądź działań wojennych,

${ }^{21}$ D. Chechelski, Kościół katolicki wobec problematyki starości, w: Aktywizacja, rozwój, integracja - ku niezależnej starości, red. Z. Szarota, Kraków 2011, s. 14. 
kiedy stosunkowo nagle potrzebne jest zorganizowanie pomocy dla dużej grupy osób.

Wsparcie duchowe wymienia się przede wszystkim w kontekście opieki hospicyjnej pacjentów śmiertelnie chorych, dla których typowe jest cierpienie i pytania o sens życia. Wówczas osoby wspierające starają się przynieść ulgę i pomóc w zaakceptowaniu sytuacji, która się wydarzyła, oraz $\mathrm{w}$ przygotowaniu chorych i ich rodzin na moment śmierci.

Wsparcie społeczne dzieli się na spostrzegane oraz otrzymywane ${ }^{22}$. Wsparcie spostrzegane i otrzymywane zależą od sytuacji, w jakiej znalazły się osoby potrzebujące wsparcia, od ich potrzeb, a także charakterystyki sieci społecznych, które są dla nich dostępne. Wsparcie spostrzegane jest rezultatem doświadczeń, wiedzy i przekonań danego człowieka na temat tego, od kogo i w jakiej formie może otrzymać wsparcie i pomoc w trudnej, stresującej sytuacji oraz na ile wsparcie i pomoc są aktualnie dostępne. Wsparcie otrzymywane określa się poprzez obiektywną ocenę zewnętrznego obserwatora bądź subiektywną reakcję osoby otrzymującej wsparcie. Można je określić jako faktycznie otrzymywany rodzaj i ilość wsparcia.

Wsparcie duchowe ze strony kapelana. Wsparcie duchowe to przede wszystkim pomoc w sytuacjach kryzysu i cierpienia duchowego, pomoc osobom w stanie terminalnym, które boją się tego, co nadejdzie. Ten rodzaj pomocy występuje $\mathrm{w}$ hospicjach i jest prowadzony przede wszystkim przez duszpasterzy. Osoby chore często poszukują sensu życia, zadają pytania egzystencjalne. Troska duszpasterska o społeczność domu pomocy społecznej, do którego kapłan jest posłany jako kapelan, wyraża się przez:

- sprawowanie liturgii Mszy Świętej (w miarę możliwości codziennie);

- sprawowanie sakramentów świętych (pokuty, namaszczenia chorych, w szczególnych przypadkach - chrztu, bierzmowania, małżeństwa); codzienne obchodzenie zakładu z Komunią św. oraz drugi raz z okazją do spowiedzi i rozmową;

- indywidualne spotkania $\mathrm{z}$ chorymi w czasie rozmów duszpasterskich;

${ }^{22}$ H. Sęk, R. Cieślak, dz. cyt., s. 21-23. 
- spotkania z personelem medycznym, szczególnie: współorganizowanie obchodów Światowego Dnia Chorego i uroczystości patrona służby zdrowia św. Łukasza, w okresie Bożego Narodzenia i Wielkanocy współorganizowanie ogólnoszpitalnych spotkań przedświątecznych, organizowanie okolicznościowych wykładów z etyki;

- opieka nad powstającymi oddziałami Katolickiego Stowarzyszenia Lekarzy Polskich i Katolickiego Stowarzyszenia Pielęgniarek i Położnych, troska o duszpasterski kontakt ze służbą zdrowia;

- troska o utrzymanie kaplicy, również biblioteki i gabloty z informacją, leży w gestii kapelana i dyrekcji szpitala;

- prowadzenie ksiąg zaopatrzonych oraz ewentualnie ksiąg metrykalnych;

- wydawanie zaświadczeń o zaopatrzeniu chorego, których z kolei parafie winny żądać od przebywających w leczeniu szpitalnym;

- informowanie zespołu duszpasterzy parafialnych i danego regionu o potrzebach duszpasterskich chorych - łącznie ze sprawozdaniem ze swej działalności duszpasterzowi diecezjalnemu ${ }^{23}$.

Pomoc instytucjonalna powinna być ukierunkowana na pomaganie rodzinom w sprawowaniu opieki nad osobami starszymi. Formą pomocy, w której instytucja nie przejmuje roli rodziny, ale ją wspomaga, są domy dziennego pobytu, gdzie osoba starsza może przebywać w czasie, gdy młodsze pokolenie pracuje bądź uczy się. Pomoc instytucjonalna powinna wspierać w opiece nad osobą starszą. Taka forma pomocy „zmusza” członków rodziny do włączenia się do opieki nad seniorami. Instytucje pomocy w tym przypadku nie przejmują roli rodziny, a jedynie ją wspierają. Rodzina nie jest instytucją dysfunkcyjną, lecz pełni obowiązki w stosunku do swoich starszych członków, przy wsparciu odpowiednio rozwiniętych $\mathrm{w}$ tym kierunku instytucji.

Dlaczego ktoś „oddaje” bliskiego do DPS-u? Jak zrozumieć rodziny, które „oddają” swoich bliskich do domów pomocy społecznej? Nie traktujmy tego zjawiska tylko w kategoriach wygodnictwa, „pozbywania się ciężaru”. Często jest to życiowa konieczność wymuszona zwykłymi, trudnymi okolicznościami, których nie jesteśmy w stanie zrozumieć,

${ }^{23}$ J. Jachimczak, W służbie życiu, Kraków 2003, s. 281-292. 
dopóki nie staniemy w sytuacji takiego wymuszonego wyboru. Czasem takie decyzje przynoszą wiele dobra tym, których dotyczą.

Zasada jest taka, że staramy się, aby osoba starsza jak najdłużej mogła przebywać w swoim środowisku naturalnym - dom-rodzina-sąsiedztwo. Dom pomocy społecznej jest ostatecznością. Zanim senior do niego trafi, staramy się mu zapewnić pomoc w dotychczasowym miejscu zamieszkania.

Osobie samotnej, która z powodu wieku, choroby lub innych przyczyn wymaga pomocy innych osób, a jest jej pozbawiona, przysługuje pomoc $\mathrm{w}$ formie usług opiekuńczych lub specjalistycznych usług opiekuńczych.

\section{SYSTEM POMOCY SPOŁECZNEJ W DPS W BROWINIE}

Dom Pomocy Społecznej w Browinie jest domem dla osób dorosłych przewlekle somatycznie chorych. Jest to najstarsza placówka w powiecie toruńskim, założona przed 70 laty; zamieszkuje w nim 125 osób (43 kobiety i 82 mężczyzn) w wieku od 27 do 98 lat.

Podstawy prawne, w oparciu o które funkcjonuje DPS: Ustawa o pomocy społecznej i Rozporządzenia Ministra Pracy i Polityki Społecznej w sprawie funkcjonowania domów pomocy społecznej z dnia 23 sierpnia 2012 r. $^{24}$ Rozporządzenie określa sposób funkcjonowania określonych typów domów pomocy społecznej, zwanych dalej „domami”, i obowiązujący standard podstawowych usług świadczonych przez domy; wzór wniosku o wydanie zezwolenia na prowadzenie domu; tryb kierowania i przyjmowania osób ubiegających się o przyjęcie do domu.

Miesięczny koszt utrzymania jednego podopiecznego w DPS w Browinie wynosi 3750,00zł. (dane z 2018 r.), z czego mieszkaniec zgodnie z ustawą pokrywa $70 \%$ ze swojego dochodu (emerytura, renta, zasiłek), pozostałe koszty ponosi rodzina, jeżeli spełnia kryteria dochodowe lub, co jest w większości przypadków, gmina kierująca podopiecznego.

${ }^{24}$ Obwieszczenie Ministra Rodziny, Pracy i Polityki Społecznej z dnia 23 marca 2018 r. w sprawie ogłoszenia jednolitego tekstu rozporządzenia Ministra Pracy i Polityki Społecznej w sprawie domów pomocy społecznej - Dziennik Ustaw Rzeczypospolitej Polskiej poz. 734 (Warszawa, dnia 13 kwietnia 2018 r.). 
a) Uposażenie finansowe mieszkańca: badania własne

\begin{tabular}{|l|c|c|}
\hline Rencista (ZUS, KRUS) & 8 Kobiety & 16 Mężczyźni \\
\hline Emerytura (ZUS, KRUS) & 29 & 32 \\
\hline Renta socjalna (ZUS) & 5 & 8 \\
\hline Zasiłki z pomocy społecznej & 1 & 26 \\
\hline
\end{tabular}

b) Relacje pomiędzy rodziną i mieszkańcem DPS: badania własne

\begin{tabular}{|l|c|c|}
\hline Osoby samotne, bez kontaktu z rodziną & 9 Kobiety & 17 Mężczyźni \\
\hline $\begin{array}{l}\text { Osoby samotne utrzymujące kontakt z dalszymi } \\
\text { krewnymi }\end{array}$ & 16 & 37 \\
\hline $\begin{array}{l}\text { Osoby, które przyszły z rodziny i utrzymują z nią stały } \\
\text { kontakt }\end{array}$ & 17 & 29 \\
\hline $\begin{array}{l}\text { Kontakt regularny/zainteresowanie i wsparcie ze strony } \\
\text { rodziny }\end{array}$ & 11 & 18 \\
\hline Kontakt regularny, wspieranie rodziny przez mieszkańca & 7 & 6 \\
\hline Kontakt sporadyczny bez wspomagania & 19 & 44 \\
\hline Brak rodziny & 5 & 15 \\
\hline Pochówkiem zajmuje się rodzina & 35 & 47 \\
\hline Pochówkiem zajmuje się DPS & 9 & 34 \\
\hline
\end{tabular}

c) Postawa roszczeniowa mieszkańców. (Badania własne) Najczęstsze to te związane z:

- brakiem wystarczających środków finansowych na zakupy (używek, np. papierosów);

- pretensjami na dokonywanie zbyt dużych potrąceń za leki, pobyt i inne niezbędne rzeczy;

- oskarżaniami o kradzież;

- niezadowoleniem ze świadczonych usług zdrowotnych;

- domaganiem się wizyt u specjalistów (często niepotrzebnych).

d) Postawa roszczeniowa rodziny względem DPS-u. Najczęściej spotykane roszczenia:

- finansowe - zbyt duże rachunki za leki, środki opatrunkowe, higieniczne, za zakup odzieży, artykułów spożywczych (ciastka, owoce, napoje) i dlaczego tak mało pieniędzy zostaje do wypłaty dla rodziny;

- bytowe - związane z obsługą i opieką, zbyt mało czasu poświęconego na opiekę indywidualną, zbyt mało zajęć terapeutycznych, wysadzania na wózki; 
- zdrowotne - zbyt mała rehabilitacja, za dużo leków, zbyt duże oczekiwania co do poprawy stanu zdrowia (rodziny oczekują nagłej poprawy stanu zdrowia, cudownego wyleczenia); zdarza się, że mieszkaniec nowo przyjęty (głównie z chorobą Alzheimera) nie może zaaklimatyzować się w nowym miejscu, co wpływa na pogorszenie stanu zdrowia, prowadzi nawet do śmierci z tęsknoty za domem, rodziną, jak w powiedzeniu, że „starych drzew się nie przesadza”.

Są też rodziny, które przez cały pobyt mieszkańca (często jest on wieloletni) utrzymują bardzo dobry kontakt z pracownikami (obsługującymi bezpośrednio i administracją), współpracują, przejawiają zaangażowanie w sprawowaniu opieki nad swoim bliskim, traktują wręcz pracowników jak najbliższą rodzinę ich bliskiego, nawet po śmierci utrzymują kontakt z personelem DPS, chcąc w ten sposób przedłużyć wspomnienia po zmarłym członku rodziny.

Pogrzeb mieszkańca. Pogrzeb mieszkańca, który posiada świadczenia z ZUS lub KRUS, jest finansowany z zasiłku pogrzebowego, nawet jeśli DPS zajmuje się pogrzebem. Natomiast osoby, które otrzymują jedynie zasiłki z pomocy społecznej, w przypadku, gdy rodzina nie zajmuje się pogrzebem, a tak jest najczęściej, wtedy pogrzebem zajmuje się DPS, ponosząc koszty związane z pochówkiem. Pracownicy i kapelan DPS zawsze uczestniczą $\mathrm{w}$ pogrzebach swoich mieszkańców.

\section{ZAKOŃCZENIE}

Odpowiedzialność za osoby starsze opiera się na wskazaniu im sensu starości. Ważne jest również to, aby potrafili oni docenić ukryte w niej walory i odrzucili pokusę buntu, izolowania się od ludzi, rezygnacji czy poczucia nieprzydatności i beznadziei.

Niezależnie od tego, jaki wariant wybiorą dzieci, sami zaopiekują się staruszkami czy opiekę przekażą innym, zawsze pozostaną wątpliwości. Dosłownie każdy, kto oddaje seniorów do ośrodka DPS tłumaczy się, że po prostu musi. Wszyscy mają wyrzuty sumienia. Mówią, że nie dadzą rady, muszą pracować i szukają miejsca, gdzie będzie profesjonalna opieka. Poświęcenie kariery, a czasem własnej rodziny, dla opieki nad rodzicem 
także nie przynosi pełnej satysfakcji. Pojawia się złość, frustracja, czasem wręcz agresja.

Nie ma więc prostej odpowiedzi na pytanie, który wariant jest lepszy. Bardzo dużo zależy od tego, w jakim stanie jest senior. Jeśli to niedołężny staruszek, ale względnie zdrowy i samodzielny, opieka codzienna polega jedynie na podwiezieniu do lekarza, gotowaniu czy praniu. Jednak jeśli mamy do czynienia $\mathrm{z}$ osobą chorą np. na Alzheimera, to wymaga ona stałej opieki i nadzoru.

Prezentowany artykuł był próbą spojrzenia na współczesny problem starzenia się społeczeństwa, które domaga się nowych wyzwań wobec wzrastającej liczby seniorów. Nie można zgodzić się na wykluczenie tej grupy społecznej, lecz należy odnaleźć sposób na ich konkretne zaangażowanie $\mathrm{w}$ życiu wspólnotowym. Istotnym zadaniem jest także zorganizowanie dla nich pomocy tak ze strony rodziny, jak i instytucji, aby w ten sposób respektować godność osoby ludzkiej, przysługującą każdemu człowiekowi.

\section{BIBLIOGRAFIA}

Benedykt XVI, Dziadkowie są cennym skarbem każdej rodziny. Przemówienie do uczestników XVIII Zgromadzenia Plenarnego Papieskiej Rady ds. Rodziny, (Watykan, 5 kwietnia 2008).

Bronowski P., Sawicka M., Kluczyńska S., Sieci społeczne osób chorujących psychicznie objętych środowiskowym programem wsparcia i rehabilitacji, „Postępy Psychiatrii i Neurologii" 4 (2008), ss. 291-298.

Chechelski D., Kościół katolicki wobec problematyki starości, w: Aktywizacja, rozwój, integracja - ku niezależnej starości, red. Z. Szarota, Kraków 2011, ss. 11-22.

Duda M., Wartość ludzkiej starości, w: Życie i śmierć. Wyzwania działalności charytatywnej, red. J. Stala, Tarnów 2012, ss. 129-139.

Dziedzic J., Spór o eutanazję, Kraków 2005.

Franciszek, Papież do duchownych: Nie kierujcie się jedynie skutecznością, (Rio de Janeiro, 27 lipca 2013).

Grabusińska Z., Domy pomocy społecznej w Polsce, Warszawa 2013.

Jachimczak J., W stużbie życiu, Kraków 2003.

Jan Paweł II, Każda polityka demograficzna musi szanować osobę ludzką. Przemówienie do Sekretarza Generalnego Międzynarodowej Konferencji na temat zaludnienia (7 czerwca 1984). 
Jan Paweł II, List „Do moich Braci i Sióstr - ludzi w podeszłym wieku” (Watykan, 1 X 1999).

Jan Paweł II, O szacunku dla ludzi w podeszłym wieku. Przemówienie do uczestników konferencji zorganizowanej przez Papieską Radę ds. Duszpasterstwa Służby Zdrowia, (31 października 1998).

Jan Paweł II, Środki przekazu społecznego a problem ludzi starszych. Orędzie na XVI Światowy Dzień Środków Masowego Przekazu, (Watykan, 10 maja 1982).

Leszczyńska-Rejchert A., Człowiek starszy i jego wspomaganie - w stronę pedagogiki starości, Olsztyn 2010.

Mielczarek A., Człowiek stary $w$ domu pomocy społecznej. Z perspektywy polityki społecznej i pracy socjalnej, Toruń 2010.

Obwieszczenie Ministra Rodziny, Pracy i Polityki Społecznej z dnia 23 marca 2018 r. w sprawie ogłoszenia jednolitego tekstu rozporządzenia Ministra Pracy i Polityki Społecznej w sprawie domów pomocy społecznej - Dziennik Ustaw Rzeczypospolitej Polskiej poz. 734 (Warszawa, dnia 13 kwietnia 2018 r.).

Papieska Rada ds. Świeckich, Godność i posłannictwo ludzi starszych (Watykan 1.10.1998). Sęk H., Cieślak R., Wsparcie społeczne - sposoby definiowania, rodzaje i źródła wsparcia. Wybrane koncepcje teoretyczne, w: Wsparcie spoleczne, stres i zdrowie, red. H. Sęk, R. Cieślak, Warszawa 2005, ss. 13-25.

Szatur-Jaworska B., Ludzie starzy i starość w polityce społecznej, Warszawa 2000.

Wiśniewska-Roszkowska K., Starość jako zadanie, Warszawa 1989.

Zagajewski A., Przyjemności marzyciela, „Tygodnik Powszechny”, 21 czerwca 2015.

Zych A. A., Człowiek wobec starości, Warszawa 1995. 